\title{
Development of a Model for Empowering Women Craftsmen Through a Partnership Pattern in Buleleng Regency, Bali
}

\author{
Ni Luh Wayan Sayang Telagawathi ${ }^{1{ }^{*}}$ Ni Made Suci ${ }^{1}$ Ni Nyoman Yulianthini ${ }^{1}$
}

\author{
${ }^{1}$ Department of Management, Universitas Pendidikan Ganesha, Singaraja, Indonesia \\ *Corresponding author. Email: gemilangsuryawan@gmail.com
}

\begin{abstract}
This article aims to develop an empowerment model for the small cepuk woven cloth industry that involves the participation of the government, companies / private sector, and tourism industry players. The entrepreneurial potential of the weaving handicraft household business is actually very promising, but the development of the business always faces various obstacles. One of the classic problems of empowering a household business is business development. That is why this applied research explores the potential for social and economic capital of the weaving handicraft business to partner with the government, private sector and tourism actors. This research tries to find potential partnership patterns to be developed in accordance with the existing context in Buleleng Regency, Bali. Empowerment of women craftsmen is chosen on the basis that it is the role of women that drives this business until now. This large potential is still constrained due to the isolation of this household business. In addition, finding innovations for business development by establishing relationships with potential parties is almost never done. So, what happens is a very potential effort to drive the household economy to become undeveloped. That is why universities have a very important role in deciphering the complexity of the problem, and then trying to find alternative partnership models for future development.
\end{abstract}

Keywords: Empowerment, Partnerships, Foster Fathers, Women Craftsmen, Weaving Crafts.

\section{INTRODUCTION}

The existence of small businesses of woven fabrics as a cultural heritage in Bali Province faces various complex problems. In the midst of its great potential to introduce woven fabrics, the various obstacles to developing small handicraft businesses have become serious obstacles. These various obstacles include capital, network marketing, and selforganization through a group of craftsmen. The estuary of all of this is that there is no strong partnership commitment from the craftsmen themselves, the government, the private sector and the tourism industry players to join hands and jointly develop the woven handicraft industry in Bali Province.

The handicraft industry in Bali has enormous potential as a driving force for the people's economy. As one of the creative industry sectors that is promising to develop, the handicraft industry operates in household groups that clearly address the economic needs of the lowly people. As a driving force for the people's economy, handicraft business is a vital potential for the development of community empowerment that still relies on small businesses.

The problem of the circle of poverty in the centers of woven cloth craftsmen is a serious problem. Woven handicraft business has not become a source of economic income for rural communities. Its development is also very slow with a limited scope of territory in the region, not yet globalized. Like a small handicraft industry, the issue of capital is a very important issue. As a handicraft business, the absorption of labor is actually very large.
The position of women is very important in driving the handicraft industry in rural areas. One of the challenges faced is the position of women who are still shackled by a patriarchal social system, in addition to the hierarchical caste system. Of the many poor people based on household units, women are the ones who receive the worst effects of poverty. The dual role, as that is how custom and the state want it, has doubled the responsibility of women compared to men. Apart from being burdened with a lot of domestic duties, they are still expected to contribute to the family economy [1], [2].

In the midst of this situation, women craftsmen are a potential driving force for small businesses, but there is no empowerment innovation that is able to develop a weaving business. Several weaving centers in Buleleng Regency, Bali are still struggling with various limitations. This shows that in fact many rural residents still rely on this handicraft industry. However, the problem of managing the woven fabric business as a whole has not been maximally developed to make this weaving business like a local street. No less important is the lack of attention and training in skills development programs in working on these woven fabrics. That is why a comprehensive empowerment effort is needed for women craftsmen to be able to make the weaving business bring them out of poverty.

Empowerment efforts in the context of taking sides with the government to the community are very much needed for the development of household-based small and medium enterprises. The empowerment strategy by utilizing their local potential is one of the development strategies that are 
implemented and developed in development activities, especially developing countries. Empowerment is the granting of authority and community capacity building. Authorization and capacity building cannot be separated. This is because if the community only gets authority but does not yet have the capacity, what will be generated is not optimal.

Empowerment efforts carried out by various parties desire to make independence the foundation of community life, including women craftsmen. Empowerment processes touch on community empowerment initiatives to be able to think and act according to what they believe [3]. That is why empowerment programs require sustainable efforts in the form of assistance and jointly formulating problems and also joint efforts to solve problems [4].

Strengthening the empowerment of women weaving craftsmen in the form of small business group institutions does not always require capital. Apart from the problem of capital, one of the main problems of small businesses is to mobilize the entrepreneurial spirit of the women craftsmen of woven fabrics in their respective regions. This great potential has not been properly explored so that the problem of women craftsmen of woven fabrics is only dealing with problems of capital and marketing, which have never been resolved. That is why an empowerment model is needed through a holistic foster father partnership that is able to get them out of the cycle of poverty.

The operation of small and medium enterprises is very much influenced by the entrepreneurial spirit itself. That is why entrepreneurial values are closely related to creativity, risk taking, innovation, achievement orientation, ambition and independence. The values possessed by an entrepreneur are very important to be developed continuously to test integrity, creativity, and innovation for future endeavours [5]. This is closely related to the process of forming an entrepreneurial spirit for each person. This formation process is closely related to everyone's decision making to see the potential that exists in themselves and their environment to be developed further.

The centers of UKM for endek woven fabrics, which are still active, are in Bondalem Village, Tejakula District, Kalianget Village, Seririt District, Sinabun Village, Sawan District, and Pacung Village, Tejakula District. The number of Buleleng UKM players in Buleleng, according to data from the Buleleng Kopdagprin Service, was 9,321 UKM. This number is divided into SMEs in the trade sector as many as 5,837 , then UKM in the agricultural industry as many as 1,568 , and UKM in the non-agricultural industry as many as 1,220 and various services as many as 696 actors [6].

\section{METHOD}

The approach of this research is qualitative research that is applied (applied) to serve as a guideline in the community, especially in developing a partnership empowerment model. Qualitative research data collection from the results of in- depth interviews and observations of the actors, the research subjects, in this case are women craftsmen of woven fabrics in two districts, namely Karangasem and Buleleng.

Qualitative research based on the participation of research subjects for social change is often referred to as qualitative research methods Participatory Action Research (RAP). RAP is a research activity carried out in a participatory manner among members of a community/broader social sphere to encourage transformative actions (changes to better living conditions), namely empowerment of business actors.

Thus, the RAP does not stop at research activities alone, but continues to empower community members in a participatory manner to take a number of actions for the improvement of their own living conditions. In addition, the RAP does not stop at the publication of research results (reports) and recommendations for further development or research proposals, but is oriented towards changing situations, increasing the knowledge and ability of the citizens to understand and change their situation for the better. In short, RAP does take part in the process of community awareness and empowerment [7].

Researchers are participatory in their research subjects, namely SMEs in Buleleng Regency. Participation observations are carried out to build arguments and theories from field data obtained by the researcher along with the research subject. The researcher uses the reflective method together with the research subjects to build a relationship pattern to jointly formulate the problems that occur and provide their arguments. This research method is classified as participatory alternative (transformative) research which believes that reality is participatory in nature created by the (relationship) mind and the existing environment. This is what is called "critical subjectivity" which occurs through our participatory transactions with our environment.

\section{RESULTS \& DISCUSSION}

We can refer to the existence of endek cloth from a book by Brigitta Hauser-Schaubin, Marie Louise Nabholz Kartaschoff entitled Textiles in Bali [8]. In their book, it is explained that initially endek was a symbol of nobility. This is because it is only used by those with high social strata. Over time, the endek cloth began to be used by various levels of society. Automatic market demand is expanding, making it a savior of the local economy. Article, endek craftsmen are usually women, most of whom are married, which makes selling this traditional cloth their main income.

The first period was in the 19th century or towards the 20th century, where the woven cloth which in the HinduBalinese tradition is called wastra is used for the purposes of custom and religious rituals. Endek woven cloth is one of the important materials apart from being the wastra for places of worship, as well as the prayer cloth for Hindus. Over time, this made him start to be produced even more. Innovations, 
including the addition of motifs, have also begun to occur in the production of endek woven fabrics. The endek motif evolved into forms of Balinese gods and puppet figures. Until 1928, changes in the technique of making the most essential endek fabrics took place.

That was the second period, namely the 1930s when the growth of Balinese endek craftsmen began to be massproduced. In Figure 1 it can be seen that the craftsmen use non-machine weaving tools (ATBM) that they rent to make traditional fabrics in their respective homes. The materials used are cotton and were initially produced in villages in Tabanan and even Nusa Penida. At this time all regions in Bali also produced endek fabrics. The entire production of these fabrics is absorbed in large quantities through marketing which started in Badung (now Denpasar City). The proof is that endek is no longer made in a certain size, but is wider with a per-meter selling system.

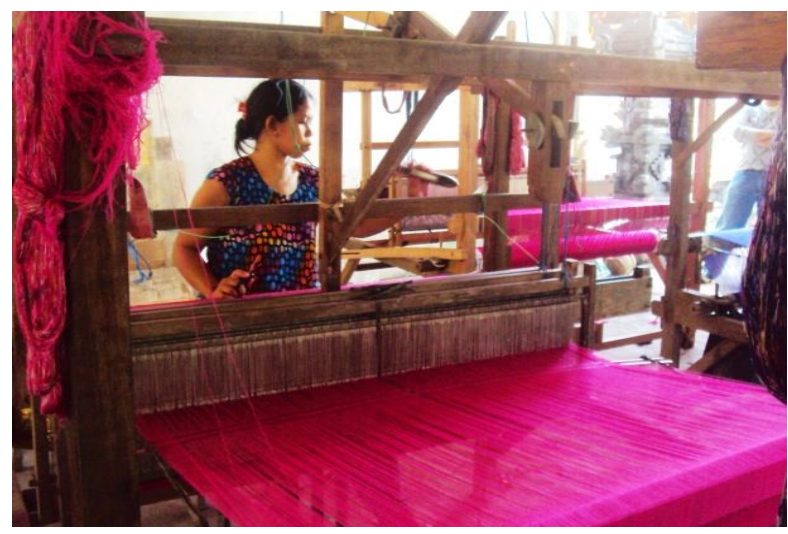

Figure 1. Yarn from dyeing and weaving processes using ATBM (Non-Machine Weaving Equipment) (photo: Ni Luh Wayan Sayang Telagawathi)

The third period is around the 1950s, after the independence period, weaving crafts, especially endek, began to develop. The regional center which is the pioneer of its development is Gianyar Regency. In the early postindependence era, there was a kind of large workshop producing endek fabrics in Gianyar. That year, there were no less than 160 producing points for Balinese endek fabrics, both in large workshops and at home.

The fourth period is around 1975 when the endek cloth was developed by craftsmen from Klungkung Regency. Starting from small businesses of housewives in the village. This household industry was then followed by several regions in Bali between 1985-1990. Each region produces different fabric motifs with a variety of color choices that make each craftsman distinctive. It was in this period that the starting point for the development of woven fabrics in the industrial world and mass produced and marketed. During this period, woven cloth was also known as one of Balinese cultural identities in the form of property pakian, or woven cloth, which began to be known on a national and international scale.
The fifth period is since 2008. This is when woven fabrics have entered the national and even international markets. Production ups and downs occurred between 2008 - 2010. Many weavers complained that the price of yarn and the basic material for making endek fabrics was expensive, so they could not produce endek fabrics in accordance with market demand [8]

Endek fabric began to develop since the XVIII century. Although endek cloth has existed since the XVIII century, endek began to develop rapidly in Bali after the independence period with the resulting diversity of motifs depicting flora, fauna, and puppet characters that often appear in Balinese mythologies. Almost all regencies and cities in Bali produce endek woven fabrics, so that each of these regions produces endek woven fabrics with different motifs, patterns, and colors from one another. This difference has caused each Regency / City in Bali to call it a different term, although it can be said that both endek fabrics, such as endek buleleng cloth, state endek cloth, endek karangasem cloth and endek klungkung cloth produced by weaving.

Weaving is a learning process that relies on hand skills and knowledge to process the raw material for yarn, as well as making designs or motifs which are then made into a piece of endek woven cloth. This weaving activity still exists and is the main source of livelihood for part of the Klungkung District community. The types of weaving that are being developed are "natural color ikat weaving" found in Tegak village, and "songket weaving in Gelgel village. There are two kinds of traditional woven fabrics that develop in this location, namely the traditional endek woven cloth, which is made by using a non-machine weaving tool (ATBM) where the fabric is woven with threaded threads that are processed manually and takes a month at the longest and woven fabrics. songket with the traditional weaving process of the cagcag loom through the process of soaking the cloth first, inserting the threads in the reeds on the cagcag is done for two days so it takes a very long time with better quality endek fabrics.

Endek and songket woven fabrics with natural dyes typical of Klungkung district are part of the art of beauty weaving that has been famous for a long time. Endek cloth is also one of the Balinese fabrics which is now very popular in Indonesia. This cloth is woven using the ikat technique, a weaving technique that is widely known throughout Indonesia. Besides functioning as religious ceremonial cloth, now endek cloth is gaining popularity as a national shirt material. Besides the endek woven cloth, songket cloth is also very popular in Balinese society. Songket is a technical term for adding a pattern to a material by filling in additional threads. The thread can be threaded throughout or only cover certain parts of a fabric. These craftsmen have a more role to play in the preservation and continuity of traditional cultural values, and are more conservative towards the value of ancestral heritage. 
As a heritage craft from our ancestors in Bali, the endek woven cloth has a high appeal because it has a distinctive pattern compared to other fabrics in Indonesia. The rich variety of woven fabrics in Bali is priceless. This cultural richness as well as cultural identity such as cepuk, songkét, prada, poléng, keling, and geringsing, and others. Cloth is not only used as a body covering in Bali. Cloth is also used to decorate ceremonial places in temples, houses, and in village centers. The Balinese people believe that there are certain fabrics that can serve as a repellent for reinforcements. Original endek fabrics such as gringsing endek, cepuk endek, and bebali endek, for example [8].

The variety of endek fabrics has a function as an antidote to the dangers of disease outbreaks, even death. Gringsing patterned endek cloth is believed to be used as an antidote to disease outbreaks. Its use is not necessarily as kamben. Endek itself has long been used as a symbol of the bonds of brotherhood. The fabric with the manufacturing process is not short-lived, especially at the coloring stage, carries a deep symbol and meaning for the Balinese people. Endek motifs are not only geometric with various sizes and patterns, as well as floral motifs, as well as gods and puppet figures who are closely related to local people's beliefs.

The wealth of woven fabrics in Bali includes various types that are scattered in various areas in Bali. This shows that these types of endek fabrics are very rich in characteristics and their own characteristics. Community groups who are engaged in woven fabrics based on the traditional and cultural heritage in their respective territories. There are at least six types of Balinese woven fabrics that have their own functions and characteristics, including: endek, songket, geringsing, cepuk, and godogang [8].

Weaving handicraft centers in Buleleng Regency are scattered in several places. The oldest Endek and Songket weaving craftsmen are in the Beratan Village, Buleleng District, which is also famous for its gold and silver handicraft production. The weaving craftsmen of Endek and Songket Beratan were also touted as craftsmen of the Buleleng Kingdom at that time.

Their weaving production supplied the royal family's cloth and clothing needs. Along with the times, Beratan's typical Endek and Songket weaving crafts have also developed to other areas, such as Jineng Dalem Village (Buleleng District), Sinabun Village (Sawan District, Buleleng), Pacung Village (Tejakula District, Buleleng), Sembiran Village (Tejakula District, Buleleng), Bondalem Village (Tejakula District, Buleleng), and Kalianget Village (Seririt District, Buleleng). A number of Buleleng's typical Endek and Songket weaving craftsmen have their own characteristics and market share. Until now, there are dozens of Endek and Songket Buleleng woven motifs.

The craftsmen who are scattered in the villages are housewives who make endek weaving a side business. The majority of women craftsmen are housewives who have the main job of taking care of children and the household. Thus, weaving becomes a side activity. This is what causes production to be low because only about $30 \%$ of the time is used for weaving. Most of it is used to take care of children and complete other household chores. Some even work in a shop first and then start weaving.

In the centers of craftsmen, many depend on endek weaving. Apart from the weaving business, there are many businesses that have been developed by the residents themselves apart from endek weaving, namely coconut collectors, river stone sellers and gas sellers in large numbers. So, if you want to try to work you will not have any difficulties. I Ketut Darma admits that the endek woven fabric business is not as fast as earning money compared to laboring (working) lifting coconuts or lifting stones. It takes more time and persistence if you want to keep trying at the endek weaving craft. He compared it to lifting a stone which after finishing immediately earned money. Because of that, the production of endek woven fabrics is less produced by housewives because of other jobs that are lucrative and bring money faster. Figure 2 shows the production process of endek woven by housewives.

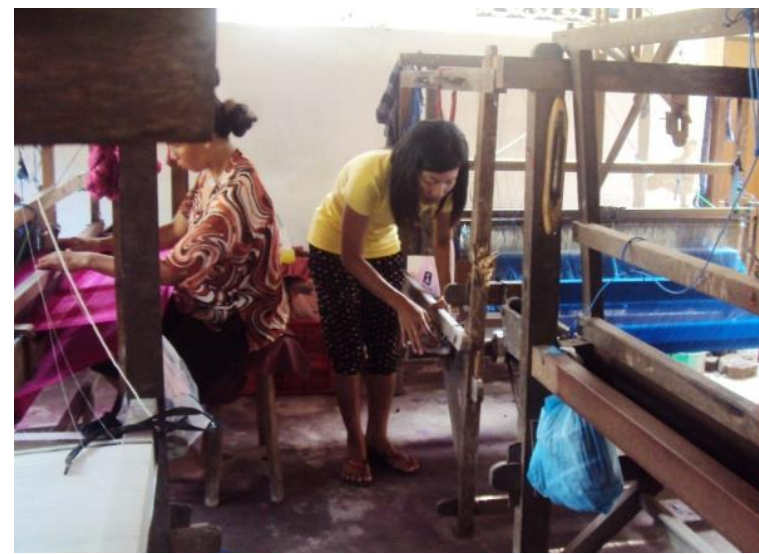

Figure 2. Weaving endek ikat is a profession for housewives in Sulang Village, Klungkung Regency. (photo: Ni Luh Wayan Sayang Telagawathi).

In the midst of the high demand for endek woven fabrics, Darma tries to fulfill some by relying on craftsmen whom he deems cager (capable) to catch the target of the customer. A large number of buyers mainly came from civil servants, PKK (Family Welfare Association), teachers to students from kindergarten (Kindergarten) to SMP (Junior High School). Many of the traders in the market regularly collect cloth from Darma's woven fabrics. Not to mention the collectors of endek fabrics in Klungkung, Gianyar, and Denpasar.

The handicraft of endek woven cloth actually gets serious attention from local governments, especially those who always promote endek cloth as the fabric produced by craftsmen in Bali. Darma often calls it "Balinese woven cloth" to distinguish it from Balinese woven cloth. What is meant by 
Balinese woven cloth is endek besides songket and cepuk. For him, those who are often sold in shops must be able to distinguish between Balinese woven fabrics and woven fabrics from outside, especially Jepara woven fabrics. What is being sold today are fabrics from Java and not Balinese woven fabrics. This is because the craftsmen in Bali have never been able to meet the production target of endek woven fabrics for the market and demand in Bali itself. This proves that the craftsmen cannot compete to produce products that can meet demand.

So according to Darma, the real problem lies not in marketing but the lack of production produced by the endek woven fabric craftsmen themselves. Darma said that the problem of raw materials was not an obstacle. The first problem is how to increase production. So far, endek craftsmen come from the home industry, where housewives only make weaving a part-time business not a priority to increase family income. Therefore, according to him, efforts are needed to increase the production of endek woven fabrics among these household weavers.

The partnership program developed for women craftsmen's weaving craft develops empowerment models that can involve various related agencies as stakeholders. Problems such as quality of production and marketing are carried out by developing distribution networks and promotions. There are four parties that will build synergies to empower the marketing of cepuk fabrics, namely the craftsmen themselves, the government, and entrepreneurs. Another model that can be developed is that the synergy between the government, the private sector and the tourism industry is very important to develop human resources for cepuk woven cloth craftsmen with a series of trainings that have been carried out by the Buleleng Regency government through the Industry Service. However, this must be continued by a synergy between the private sector and the tourism industry so that the results of the training can be directly maximized by a series of cooperation with the private sector and the tourism industry in the marketing sector or the foster father system, for example.

\section{CONCLUSION}

The problem in empowering women weaving craftsmen lies in the production process of woven fabrics that must be improved. The real problem lies not in the marketing but the lack of production produced by the endek woven fabric craftsmen themselves. That is why the partnership model by synergizing the government, private sector, and the tourism industry is very possible. The main problem is how to increase production. So far, endek craftsmen come from the home industry, where housewives only make weaving a part-time business not a priority to increase family income. Therefore, efforts are needed to increase the production of endek woven fabrics among these household weavers.

\section{ACKNOWLEDGMENT}

I would like to express my gratitude for the assistance provided by the weaving craftsmen in Buleleng Regency, especially the women craftsmen of Buleleng endek in various places I have met.

\section{REFERENCES}

[1] N. L. Arjani, "Feminisasi Kemiskinan dalam Kultur Patriarki," J. Stud. Gend. Srikandi, vol. 6, no. 1, pp. 1-10, 2007, [Online]. Available: https://ojs.unud.ac.id/index.php/srikandi/article/download /2878/2052.

[2] N. K. S. Utami, "Mengikis Ketidakadilan Gender Dalam Adat Bali," Srikandi, vol. VIII, no. 1, pp. 34-43, 2006, [Online]. Available: https://ojs.unud.ac.id/index.php/srikandi/article/view/289 3.

[3] K. Widjajanti, "Model Pemberdayaan Masyarakat," J. Ekon. Pembang. Kaji. Masal. Ekon. dan Pembang., vol. 12, no. 1, p. 15, 2011, doi: 10.23917/jep.v12i1.202.

[4] L. Chabib, Y. Febrianti, A. Hakim, M. Safarullah, and B. Subekti, "Pemberdayaan Dan Pengembangan Ukm Sebagai Penggerak Ekonomi Desa. (Desa Harjobinangun, Pakem, Sleman, Di Yogyakarta)," Ajie, vol. 1, no. 3, pp. 203-209, 2016, doi: 10.20885/ajie.vol1.iss3.art4.

[5] S. Sukirman, "Jiwa Kewirausahaan dan Nilai Kewirausahaan Meningkatkan Kemandirian Usaha melalui Perilaku Kewirausahaan," J. Ekon. dan Bisnis, vol. 20, no. 1, p. 117, 2017, doi: 10.24914/jeb.v20i1.318.

[6] I. W. Dipta, "Strategi Penguatan Usaha Mikro, Kecil Dan Menengah (UMKM) Melalui Kerjasama Kemitraan Pola CSR," in Infokop, vol. 16, 2008, pp. 62-75.

[7] S. Soetomo, "Riset Aksi Partisipatif Sebagai Pemberdayaan Dalam Pengembangan Pendidikan Perencanaan," Jurnal Tata Loka, vol. 5, no. 2. 2003.

[8] B. Hauser-Schaublin, M.-L. N.-K. Ramseyer, and Urs, Textiles in Bali. Berkeley: Periplus, 1991. 